\title{
Sodium/lodide Cotransporter
}

National Cancer Institute

\section{Source}

National Cancer Institute. Sodium/lodide Cotransporter. NCI Thesaurus. Code C17536.

Sodium/iodide cotransporter ( $643 \mathrm{aa}, \sim 69 \mathrm{kDa}$ ) is encoded by the human SLC5A5 gene.

This protein is involved in sodium-dependent iodide transport in the thyroid gland. 